\title{
Water and soil properties in organic and conventional paddies throughout the rice cultivation cycle in South Korea
}

\author{
Tae-Gu Lee ${ }^{1}$, Chang-Gu Lee ${ }^{2}$, Seung-Gil Hong ${ }^{3}$, Jin-Ho Kim³, Seong-Jik Park ${ }^{{ }^{\dagger}}$ \\ ${ }^{1}$ Department of Bioresources and Rural Systems Engineering, Hankyong National University, Anseong 17579, Republic of Korea \\ ${ }^{2}$ Department of Environmental and Safety Engineering, Ajou University, Suwon 16499, Republic of Korea \\ ${ }^{3}$ National Institute of Agricultural Sciences, Rural Development Administration, Wanju 55365, Republic of Korea
}

\begin{abstract}
Water and soil properties in paddy fields subjected to organic and conventional farming were characterized over the rice cycle in South Korea. To achieve the goals of this study, we sampled and analyzed soil and water from 24 organic paddy plots and 11 conventional paddy plots in March, May, August, and October 2016. The results were analyzed using statistical analyses, including analysis of variance (ANOVA), cluster analysis, and principal component analysis. The ANOVA results showed that water content (WC), electrical conductivity (EC), organic matter $(\mathrm{OM})$, and available phosphorus $\left(\mathrm{P}_{2} \mathrm{O}_{5}\right)$ in soil varied significantly $(p<0.01)$ depending on the farming method. Higher $\mathrm{OM}, \mathrm{EC}$, and $\mathrm{P}_{2} \mathrm{O}_{5}$ of soil were observed in the conventional paddies than in the organic paddies. All soil properties, except $\mathrm{pH}$ and ammonium, depended on seasonal variation. Cluster analysis revealed that soil properties in May were distinctly separated from those in other seasons mainly due to basal fertilization. The principal component analysis distinguished the soil properties in different seasons, but such a distinction was not observed between the soil properties in organic and conventional paddies. Low contents of WC, OM, and total N were observed in March. High concentrations of nitrate and total $\mathrm{P}$ were observed in May, but these were low in August and October. The soils from October were also characterized by high concentrations of EC and $\mathrm{P}_{2} \mathrm{O}_{5}$. These results indicate that the sampling time for soil and water can significantly influence the evaluation of soil properties with different farming methods.
\end{abstract}

Keywords: Conventional paddy, Farming method, Organic paddy, Seasonal variation, Soil, Water

\section{Introduction}

A large variety of agro-chemicals, such as pesticides, herbicides, antibiotics, hormones, and chemical fertilizers, have been used in intensive agricultural production systems. This use has been followed by deterioration of soil health and contamination of water and food chains [1]. For safe and sustainable food production, some farmers have adopted and attempted to employ management techniques that protect the environment and improve biological and natural processes [2]. Organic agriculture has been considered as an alternative strategy to conventional farming to maintain soil health and protect the environment by eliminating the use of synthetic chemicals [3], although lower production by organic farming compared to conventional production systems has been reported [4].

Both positive and negative effects of organic farming on soil and water properties have been reported. Lower $\mathrm{N}$ inputs in organic cropping systems than in conventional farming systems have led to lower $\mathrm{N}$ surplus, and thus less severe nitrate $\left(\mathrm{NO}_{3}-\mathrm{N}\right)$ contamination of groundwater [5]. However, Marchand et al. [6] reported that organic farming loses its environmental performance at high $\mathrm{N}$ levels, and that during the initial conversion period to organic farming, newly converted organic farmers increase the use of $\mathrm{N}$ to compensate for potential yield losses. Marinari et al. [7] also reported that the organic management increased the levels of total $\mathrm{N}(\mathrm{T}-\mathrm{N}), \mathrm{NO}_{3}-\mathrm{N}$, and available phosphorus $\left(\mathrm{P}_{2} \mathrm{O}_{5}\right)$. Organic management is expected to increase soil organic matter content (OM) [8-10], but such observations, even in long-term trials, have not been reported in other literature [11]. Different farming systems did not show significant differences in soil and water quality in a studied watershed in southeastern Brazil [12]. In addition to improvements in soil chemical properties, increases
This is an Open Access article distributed under the terms of the Creative Commons Attribution Non-Commercial License (http://creativecommons.org/licenses/by-nc/3.0/) which permits unrestricted non-commercial use, distribution, and reproduction in any medium, provided the original work is properly cited.

Copyright (C) 2019 Korean Society of Environmental Engineers
Received December 27, 2017 Accepted May 22, 2018

$\dagger$ Corresponding author

Email: parkseongjik@hknu.ac.kr

Tel: +82-31-670-5131 Fax: +82-31-670-5139

ORCID: 0000-0003-2122-5498 
in microbial biomass activity have been observed in organic farming [7, 13]. Organic farming systems can reduce soil erosion from fields of row crops because of the development of weeds in the furrows, but reduced crop yield due to competition with weeds can produce higher rates of erosion [14]. Eltun et al. [15] also observed both lower and higher rates of erosion on organic farms, namely lower soil erosion for organic arable crops, but higher erosion for organic forage crops compared with conventional farming. However, individual studies designed to assess the influence of organic farming on soil quality have been performed at different times, and they observed very different influences of the two farming systems.

Rice (Oryza sativa L.) is cultivated in a continually flooded condition; thus, weed control is easier than for other crops cultivated in upland conditions. Therefore, organic farming in rice paddy production is more widespread than organic farming of other crops. However, comparative studies between conventional and organic farming of paddy rice fields are scarce. In this study, soil and water quality in organic and conventional paddy fields were investigated throughout the rice cultivation cycle. Our research is valuable because few studies have compared the soil and water environments of organic and conventional paddy fields throughout the rice cultivation cycle. We also considered the impacts of seasonal variation on soil and water properties in this study. To achieve these goals, we sampled soil and water from 24 organic paddy plots and 11 conventional paddy plots in the months of March, May, August, and October. Hydrogen ion concentration $(\mathrm{pH})$, electrical conductivity (EC), OM, T-N, ammonium $\left(\mathrm{NH}_{4}-\mathrm{N}\right), \mathrm{NO}_{3}-\mathrm{N}$, total phosphorus (T-P), and $\mathrm{P}_{2} \mathrm{O}_{5}$ of soil and $\mathrm{pH}$, EC, T-N, ammonia $\left(\mathrm{NH}_{3}-\mathrm{N}\right)$, nitrite $\left(\mathrm{NO}_{2}-\mathrm{N}\right), \mathrm{NO}_{3}-\mathrm{N}$, T-P, phosphate $\left(\mathrm{PO}_{4}-\mathrm{P}\right)$, suspended solids (SS), dissolved oxygen (DO), and chemical oxygen demand (COD) of water were analyzed.

\section{Materials and Methods}

\subsection{Experimental Field}

This study was conducted in two adjacent regions, namely Yongin and Anseong cities. Soils were collected four times (March, May, August, and October) and water was collected two times (May and August) in 2016. Water and soil from 14 organic paddy plots and 4 conventional paddy plots in Yongin and from 10 organic paddy plots and 7 conventional paddy plots in Anseong were

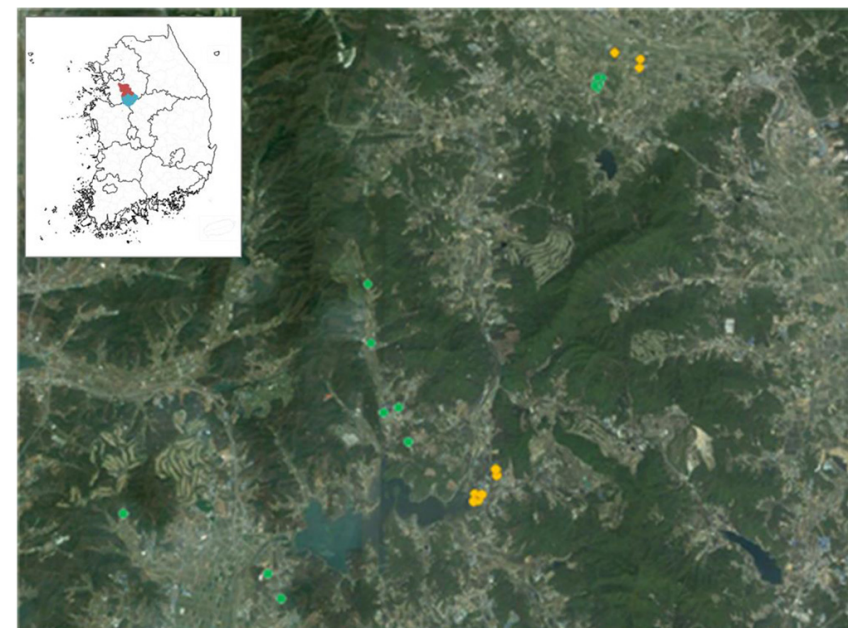

Fig. 1. Map showing the distribution of soil samples from conventional (yellow circles) and organic (green circles) paddy in Yongin and Anseong, Republic of Korea.

sampled and analyzed. All organic and conventional plots were located within the same watershed boundary of each region, and the ridge was located at the boundary between Yongin and Anseong, as shown in Fig. 1. The area of the plots ranged from $486 \mathrm{~m}^{2}$ to $5,075 \mathrm{~m}^{2}$. The organic paddy plots had been under organic production for more than 15 years. Triplicate composite soil samples were collected from the top soil $(0-15 \mathrm{~cm})$ at each plot, and water samples were also collected at three points in each plot.

The rice paddy growth stages and the fertilization, tillage, and weeding times are illustrated in Table 1. The month of March was before basal fertilization, May was after basal fertilization, August was after additional fertilization, and October was after harvesting. Animal manure was used as the basal fertilizer in both organic and conventional paddies. For additional fertilizer in organic paddies, expeller cake fertilizer composed of $4 \% \mathrm{~N}$, $2 \% \mathrm{P}$, and $1 \% \mathrm{~K}$ was used.

\subsection{Analysis of Soil and Water Quality}

For the analysis of the chemical properties of the soils, the soil samples obtained from three points at each plot were mechanically mixed, air-dried, and sieved using a US standard sieve No. 10 ( $2 \mathrm{~mm}$ ). Water content was determined by measuring the difference in weight before and after drying at $105^{\circ} \mathrm{C}$ for $24 \mathrm{~h}$. Particle size

Table 1. Rice Cropping System Including Rice Growth Stage, Fertilization, Tillage, and Weed-killing

\begin{tabular}{|c|c|c|c|c|c|c|c|}
\hline & March & April & May & July & August & September & October \\
\hline $\begin{array}{l}\text { Rice } \\
\text { growth }\end{array}$ & & & Sowing Season & & $\begin{array}{l}\text { Heading } \\
\text { Stage }\end{array}$ & $\begin{array}{l}\text { Ripening } \\
\text { Stage }\end{array}$ & $\begin{array}{l}\text { Harvesting } \\
\text { Time }\end{array}$ \\
\hline $\begin{array}{l}\text { Sampling } \\
\text { date }\end{array}$ & 25 & & 6 & & 12 & & 21 \\
\hline $\begin{array}{l}\text { Conventional } \\
\text { paddy }\end{array}$ & & $\begin{array}{c}\text { Tillage (22-28) } \\
\text { Basal Fertilizer (26-30) }\end{array}$ & $\begin{array}{l}\text { Flooding (2-9) } \\
\text { Seeding (15-19) }\end{array}$ & Additional Fertilizer (8-15) & $\begin{array}{l}\text { Flooding } \\
\quad(1-4)\end{array}$ & & $\begin{array}{l}\text { Harvesting } \\
\quad(13-20)\end{array}$ \\
\hline $\begin{array}{l}\text { Organic } \\
\text { paddy }\end{array}$ & & $\begin{array}{c}\text { Tillage (14-25) } \\
\text { Basal Fertilizer (18-25) }\end{array}$ & $\begin{array}{l}\text { Flooding (1-9) } \\
\text { Seeding (13-23) }\end{array}$ & $\begin{array}{l}\text { Additional Fertilizer (3-6) } \\
\text { Flooding (24-28) }\end{array}$ & & & $\begin{array}{c}\text { Harvesting } \\
\quad(9-27)\end{array}$ \\
\hline
\end{tabular}


distribution was analyzed according to ASTM D422 using US standard sieves Nos. 4-200 and a hydrometer. For pH and EC, $50 \mathrm{~mL}$ of deionized water was shaken with $10 \mathrm{~g}$ of soil for $1 \mathrm{~h}$, and the $\mathrm{pH}$ and $\mathrm{EC}$ of the solution were measured using a $\mathrm{pH} / \mathrm{EC}$ meter (SevenMulti S40, Mettler Toledo, Switzerland). OM was determined by the loss of weight by heating at $450^{\circ} \mathrm{C}$ for $2 \mathrm{~h}$. T-P concentration in soil was determined by the ascorbic method after digestion of soil with $\mathrm{HClO}_{4} \cdot \mathrm{P}_{2} \mathrm{O}_{5}$ concentration was measuring according to the Lancaster method ( $5 \mathrm{~g}$ of soil was extracted with $20 \mathrm{~mL}$ of $0.33 \mathrm{M} \mathrm{CH}_{3} \mathrm{COOH}, 0.15 \mathrm{M}$ lactic acid, $0.03 \mathrm{M}$ $\mathrm{NH}_{4} \mathrm{~F}, 0.05 \mathrm{M}\left(\mathrm{NH}_{4}\right)_{2} \mathrm{SO}_{4}$, and $0.2 \mathrm{M} \mathrm{NaOH}$ at a $\mathrm{pH}$ of 4.25). T-N concentration was measured according to the Kjeldahl method; soil samples were digested at $400^{\circ} \mathrm{C}$ for $4 \mathrm{~h}$ using a mixture of $\mathrm{K}_{2} \mathrm{SO}_{4}$ and $\mathrm{CuSO}_{4}$ (9:1 molar ratio) as a catalyst. $\mathrm{NH}_{4}-\mathrm{N}$ was measured using the colorimetric method after extraction from $5.0 \mathrm{~g}$ of soil with $50 \mathrm{~mL}$ of $2 \mathrm{M} \mathrm{KCl}$ followed by filtration with a glass filter (GF/C, $1.2 \mu \mathrm{m}$ pore size, Whatman, USA). $\mathrm{NO}_{3}-\mathrm{N}$ was measured using the Brucine method after extraction with $2 \mathrm{M} \mathrm{KCl}$.

Water quality was analyzed according to Korean standard methods for analysis of water quality. $\mathrm{DO}$ and $\mathrm{pH} / \mathrm{EC}$ were measured using a DO meter (HI 9146, Hanna, Romania) and a pH/EC meter, respectively. COD was measured using the chromic acid method, in which samples are oxidized by $\mathrm{K}_{2} \mathrm{Cr}_{2} \mathrm{O}_{7}$. SS were determined by measuring the difference in weight before and after filtering $1 \mathrm{~L}$ water samples with a GF/C filter $(1.2 \mu \mathrm{m}$, Whatman, USA). T-P was measured using the ascorbic acid reduction method after digestion with $\mathrm{K}_{2} \mathrm{~S}_{2} \mathrm{O}_{8}$, and $\mathrm{PO}_{4}-\mathrm{P}$ was measured using the stannous chloride method. T-N was analyzed with a UV spectrophotometer (Optizen POP QX, Mecasys Co., Republic of Korea) after thermal decomposition using $\mathrm{NaOH}$ and $\mathrm{K}_{2} \mathrm{~S}_{2} \mathrm{O}_{8}$. $\mathrm{NH}_{3}-\mathrm{N}$ was analyzed using the indophenol method and $\mathrm{NO}_{3}-\mathrm{N}$ was analyzed using the Brucine method. $\mathrm{NO}_{2}-\mathrm{N}$ was analyzed using a UV spectrophotometer at $540 \mathrm{~nm}$ after reacting the sample with sulfanilamide and $\alpha$-naphthyl ethylenediamine dihydrochloride.

\subsection{Data Analysis}

A one-way analysis of variance (ANOVA) was conducted to compare the means of the different treatments. When significant $F$-values were detected, the differences between individual means were tested using Duncan's multiple range tests. To classify objects characterized by a set of variables into groups, clustering methods were used [16]. Cluster analysis is an explorative analysis method that identifies structures within the data. A hierarchical clustering was used to delineate relationships among groups. Hierarchical clustering analyses were performed on soil and water properties, which were grouped according to their similarity to each other. Ward's linkage method [17] was used in this analysis. To reduce the number of variables through linear combinations of the original variables of soil chemical properties, principal component analysis was used [18]. All statistical analyses were performed using SAS 9.4 (SAS Institute Inc., Cary, NC, USA).

\section{Results and Discussion}

\subsection{ANOVA Results for Soil Properties and Water Quality}

In the comparison of organic and conventional paddies, WC, EC, $\mathrm{OM}$, and $\mathrm{P}_{2} \mathrm{O}_{5}$ presented significant variation (Table 2). All soil properties, except $\mathrm{pH}$ and $\mathrm{NH}_{4}-\mathrm{N}$, varied significantly throughout the rice cultivation cycle, and the significance of their difference was very high ( $p$-values were less than 0.0001). EC and $\mathrm{P}_{2} \mathrm{O}_{5}$ were slightly influenced by the interaction effects of farming type and temporal variation. The ANOVA results showed that temporal variation influenced soil quality in rice paddies more significantly than in other types of farming.

Water quality in organic and conventional paddies throughout the rice cycle was analyzed statistically, and the results are shown in Table 3. Organic and conventional paddies differed significantly only for $\mathrm{pH}$ and $\mathrm{EC}$ among the water quality properties. T-P, $\mathrm{PO}_{4}-\mathrm{P}, \mathrm{SS}$, and COD varied significantly throughout the rice cycle, and $\mathrm{pH}$, T-P, and COD were found to be dependent on the interaction of farming type and season. The ANOVA results for soil properties and water quality showed that soil properties were more significantly influenced by temporal variation than water quality.

\subsection{Cluster Analysis}

Hierarchical cluster analysis was applied for soil properties, and the results are presented in Fig. S1. The method was not able to differentiate farming methods because conventional and organic farming clustered together. However, we did find that the soil properties in May were distinctly separated from those of the other seasons. Such an observation was not found in the water quality data, and all variables, including region, farming method, and seasonal variation, had no influence on the clustering of the

Table 2. ANOVA for Chemical Properties with Regard to Farming Method and Seasonal Variation

\begin{tabular}{|c|c|c|c|c|c|c|c|c|c|c|}
\hline \multirow[b]{2}{*}{ Source } & \multirow[b]{2}{*}{ DF } & \multicolumn{9}{|c|}{ Mean Square } \\
\hline & & $\begin{array}{c}\text { Water } \\
\text { Content }\end{array}$ & $\begin{array}{c}\text { pH } \\
(1: 5)\end{array}$ & $\begin{array}{c}\text { EC } \\
\left(\mu \mathrm{S}^{-\mathrm{cm}^{-1}}\right)\end{array}$ & $\begin{array}{l}\text { OM } \\
(\%)\end{array}$ & $\begin{array}{c}\mathrm{T}-\mathrm{N} \\
\left(\mathrm{mg} \mathrm{kg}^{-1}\right)\end{array}$ & $\begin{array}{c}\mathrm{NH}_{4}-\mathrm{N} \\
\left(\mathrm{mg} \mathrm{kg}^{-1}\right)\end{array}$ & $\begin{array}{c}\mathrm{NO}_{3}-\mathrm{N} \\
\left(\mathrm{mg} \mathrm{kg}^{-1}\right)\end{array}$ & $\begin{array}{c}\mathrm{T}-\mathrm{P} \\
\left.(\mathrm{mg} \mathrm{kg})^{-1}\right)\end{array}$ & $\begin{array}{c}\mathrm{P}_{2} \mathrm{O}_{5} \\
\left(\mathrm{mg} \mathrm{kg}^{-1}\right)\end{array}$ \\
\hline Farming (F) & 1 & $284.0^{* *}$ & $0.8^{\mathrm{ns}}$ & $80,092.1^{* *}$ & $64.5^{* *}$ & $92,929.0^{\mathrm{ns}}$ & $1.4^{\mathrm{ns}}$ & $968.5^{\mathrm{ns}}$ & $973,746.9^{\mathrm{ns}}$ & $428.0^{*}$ \\
\hline Season (S) & 3 & $842.6^{* * *}$ & $0.3^{\mathrm{ns}}$ & $126,411.8^{* * *}$ & $46.4^{* *}$ & $408,500.8^{* *}$ & $421.2^{\mathrm{ns}}$ & $28,142.7^{* * *}$ & $5,501,958.5^{* * *}$ & $3,636.0^{* * *}$ \\
\hline $\mathrm{F} \times \mathrm{S}$ & 3 & $14.6^{\mathrm{ns}}$ & $0.2^{\mathrm{ns}}$ & $18,446.5^{*}$ & $6.0^{\mathrm{ns}}$ & $110,301.9^{\mathrm{ns}}$ & $63.4^{\mathrm{ns}}$ & $3,151.3^{\mathrm{ns}}$ & $17,751.0^{\mathrm{ns}}$ & $562.2^{*}$ \\
\hline Error & 130 & 25.6 & 0.3 & $5,807.0$ & 7.0 & $65,647.3$ & 181.8 & $1,317.0$ & $115,091.5$ & 172.7 \\
\hline
\end{tabular}

ns values are statistically not significant, ${ }^{*}$ values are statistically significant at $p<0.05,{ }^{* *}$ values are statistically significant at $p<0.01$,

${ }^{* * *}$ values are statistically significant at $p<0.0001$ 
Table 3. ANOVA for Water Quality with Regard to Farming Method and Seasonal Variation

\begin{tabular}{|c|c|c|c|c|c|c|c|c|c|c|c|}
\hline \multirow[b]{2}{*}{ Source } & \multirow[b]{2}{*}{ DF } & \multicolumn{10}{|c|}{ Mean Square } \\
\hline & & $\begin{array}{c}\text { pH } \\
(1: 5)\end{array}$ & $\begin{array}{c}\mathrm{EC} \\
\left(\mu \mathrm{S}^{-1} \mathrm{~cm}^{-1}\right)\end{array}$ & $\begin{array}{c}\text { T-N } \\
\left(\mathrm{mg} \mathrm{L}^{-1}\right)\end{array}$ & $\begin{array}{c}\mathrm{NH}_{3}-\mathrm{N} \\
\left(\mathrm{mg} \mathrm{L}^{-1}\right)\end{array}$ & $\begin{array}{c}\mathrm{NO}_{2}-\mathrm{N} \\
\left(\mathrm{mg} \mathrm{L}^{-1}\right)\end{array}$ & $\begin{array}{c}\mathrm{NO}_{3}-\mathrm{N} \\
\left(\mathrm{mg} \mathrm{L}^{-1}\right)\end{array}$ & $\begin{array}{c}\text { T-P } \\
\left(\mathrm{mg} \mathrm{L}^{-1}\right)\end{array}$ & $\begin{array}{c}\mathrm{PO}_{4}-\mathrm{P} \\
\left(\mathrm{mg} \mathrm{L}^{-1}\right)\end{array}$ & $\begin{array}{c}\text { SS } \\
\left(\mathrm{mg} \mathrm{L}^{-1}\right)\end{array}$ & $\begin{array}{c}\text { COD } \\
(\mathrm{ppm})\end{array}$ \\
\hline Farming (F) & 1 & $6.2^{\star \star \star \star}$ & $229,662.8^{* * *}$ & $0.0^{\mathrm{ns}}$ & $11.6^{\mathrm{ns}}$ & $0.0^{\mathrm{ns}}$ & $0.5^{\mathrm{ns}}$ & $0.1^{\mathrm{ns}}$ & $0.1^{\mathrm{ns}}$ & $35,066.9^{\mathrm{ns}}$ & $52.0^{\mathrm{ns}}$ \\
\hline Season (S) & 1 & $0.2^{\mathrm{ns}}$ & $968.5^{\mathrm{ns}}$ & $0.0^{\mathrm{ns}}$ & $10.7^{\mathrm{ns}}$ & $0.0^{\mathrm{ns}}$ & $0.3^{\mathrm{ns}}$ & $0.2^{*}$ & $0.8^{* * *}$ & $138,623.2^{* *}$ & $2,292.4^{*}$ \\
\hline $\mathrm{F} \times \mathrm{S}$ & 1 & $2.1^{* * *}$ & $22.9^{\mathrm{ns}}$ & $2.0^{\mathrm{ns}}$ & $22.7^{\mathrm{ns}}$ & $0.0^{\mathrm{ns}}$ & $0.2^{\mathrm{ns}}$ & $0.2^{*}$ & $0.1^{\mathrm{ns}}$ & $39,287.5^{\mathrm{ns}}$ & $2,090.9^{*}$ \\
\hline Error & 65 & 0.1 & $5,468.6$ & 2.9 & 6.7 & 0.0 & 0.7 & 0.0 & 0.0 & $16,485.5$ & 428.2 \\
\hline
\end{tabular}

ns values are statistically not significant, "values are statistically significant at $p<0.05,{ }^{* *}$ values are statistically significant at $p<0.01$, ${ }^{* * *}$ values are statistically significant at $p<0.0001$

water quality data (Fig. S2). The influence of the variables on soil and water quality properties could not be studied by hierarchical cluster analysis. Therefore, for this study, principal component analysis was determined to be a suitable method.

\subsection{Principal Component Analysis of Soil Properties and Water Quality}

Principal component analysis of soil properties was performed following the ANOVA, which demonstrated significant differences among region, farming type, and temporal variation. $\mathrm{pH}$ and $\mathrm{NH}_{4}-\mathrm{N}$ showed no significant difference between treatments at the $p<0.05$ level; thus, only 7 of the 9 soil properties were considered for the principal component analysis. The principal component analysis of the remaining 7 variables resulted in three principal components having eigenvalues > 1 and accounting for $66.0 \%$ of the total variance in the data (Table 4). The proportions of the soil properties data explained by PC1, PC2, and PC3 were 23.3\%, 22.2\%, and 20.5\%, respectively. T-N was the greatest contributor to $\mathrm{PC} 1$, but two additional variables, namely $\mathrm{WC}$ and $\mathrm{OM}$, also had highly weighted factor loadings. For PC2 and PC3, two variables in each had high factor loadings, namely $\mathrm{NO}_{3}-\mathrm{N}$ and T-P for PC2 and EC and $\mathrm{P}_{2} \mathrm{O}_{5}$ for PC3.

The principal component analysis plot (Fig. 2) allowed the distinction of some groups of samples, and these groups were distinctive depending on temporal variation. The soil samples obtained in March had low contents of WC, OM, and T-N, but these were high in soil samples from August. The soils from May were characterized by high concentrations of $\mathrm{NO}_{3}-\mathrm{N}$ and $\mathrm{T}-\mathrm{P}$, but those from August and October presented low concentrations of $\mathrm{NO}_{3}-\mathrm{N}$ and T-P. The soils from October were also characterized by high concentrations of EC and $\mathrm{P}_{2} \mathrm{O}_{5}$. The properties of the soil sampled in March were distributed in the middle of the principal component analysis plot and were mixed with the results obtained from other seasons. A distinction between the properties of organic and conventional paddy soil was not shown in the principal component analysis plot, and these results followed the same trend as those obtained from the ANOVA.

In the principal component analysis for water quality, T-N, $\mathrm{NH}_{3}-\mathrm{N}, \mathrm{NO}_{2}-\mathrm{N}$, and $\mathrm{NO}_{3}-\mathrm{N}$, which were insignificant depending on treatment in the ANOVA, were not used, and only 6 of the 10 water quality properties were considered in the analysis. The principal component analysis revealed that $75.7 \%$ of the data
Table 4. Eigenvalues and Eigenvectors of Soil Properties Obtained from the Principal Component Analysis

\begin{tabular}{lccc}
\hline & PC1 & PC2 & PC3 \\
\hline Eigenvalues & 1.629 & 1.556 & 1.432 \\
\% Variance & 23.3 & 22.2 & 20.5 \\
\hdashline $\mathrm{WC}$ & 0.735 & -0.129 & 0.094 \\
$\mathrm{EC}$ & -0.034 & -0.183 & 0.868 \\
$\mathrm{OM}$ & 0.619 & -0.171 & -0.245 \\
$\mathrm{~T}-\mathrm{N}$ & 0.779 & 0.176 & -0.077 \\
$\mathrm{NO}_{3}-\mathrm{N}$ & 0.128 & 0.827 & 0.157 \\
$\mathrm{~T}-\mathrm{P}$ & -0.264 & 0.836 & -0.115 \\
$\mathrm{P}_{2} \mathrm{O}_{5}$ & -0.107 & 0.249 & 0.752 \\
\hline
\end{tabular}

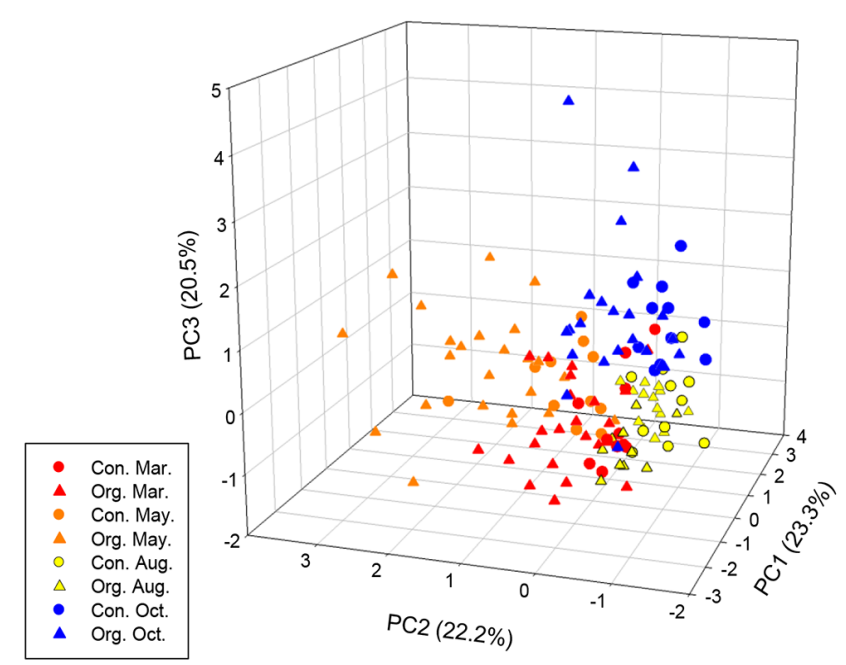

Fig. 2. Principal component analysis of soil chemical properties. The variance explained by each principal component (PC) axis is shown parentheses. Colors refer to the time of soil sampling (Red: March, Orange: May, Yellow: August, Blue: October). Con: Conventional paddy, Org: Organic paddy.

of the 6 parameters tested was explained by three PCs with ei genvalues $>1$ (Table S1). The percentages of total variance ac counted for by PC1, PC2, and PC3 were 39.6\%, 18.6\%, and 17.5\%, respectively. $\mathrm{pH}, \mathrm{EC}, \mathrm{T}-\mathrm{P}$, and $\mathrm{PO}_{4}-\mathrm{P}$ had high intraset correlations 


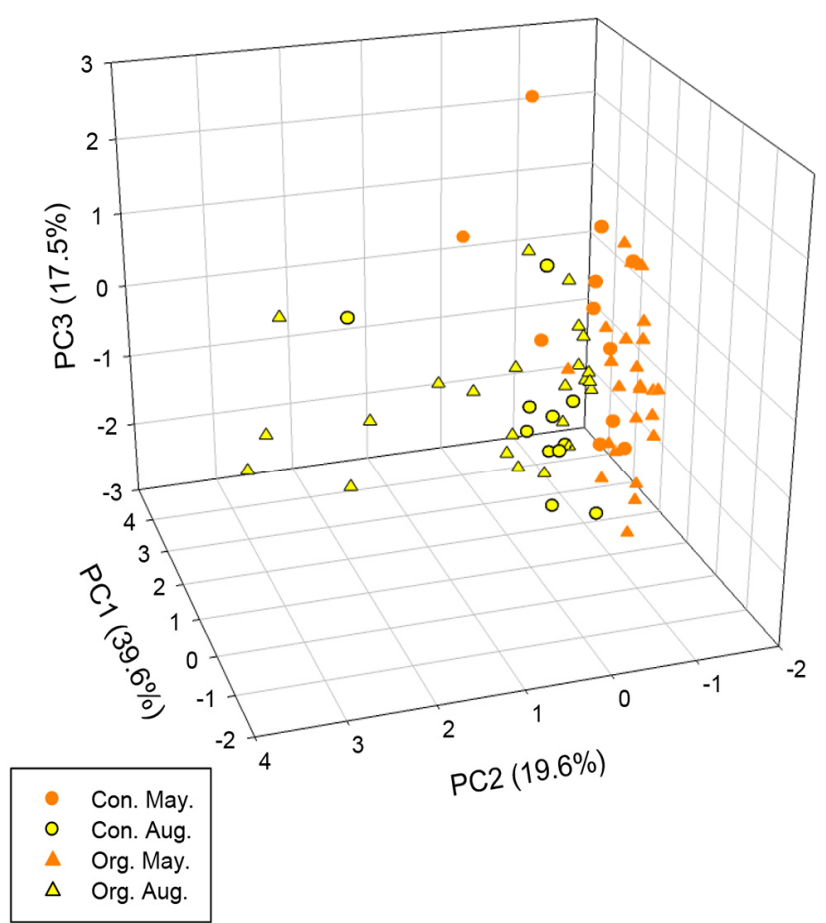

Fig. 3. Principal component analysis of water quality. The variance explained by each principal component (PC) axis is shown in parentheses. Colors refer to the time of soil sampling (Orange: May, Yellow: August). YC: Yongin conventional paddy, YO: Yongin organic paddy, AC: Anseong conventional paddy, AO: Anseong organic paddy.

with PC1 (0.696, 0.790, 0.800, and 0.793, respectively), and SS and COD presented high intraset correlations with PC2 and PC3, respectively.

The 3-D principal component plot obtained from the principal component analysis of the water quality data is presented in Fig. 3. Higher concentrations of SS were observed in August than in May, and this observation was especially distinct for organic paddies. The ponded water of the conventional paddies in August had high $\mathrm{pH}, \mathrm{EC}, \mathrm{T}-\mathrm{P}$, and $\mathrm{PO}_{4} \mathrm{P}$. In August, a difference in water quality between organic and conventional farming was observed. Water quality results were dependent on the farming method as well as seasonal variation. The influence of seasonal variation on soil properties and water quality could be inferred from various factors, including fertilization, plant growth, irrigation, and depth of ponded water. Therefore, when analyzing soil properties and water quality in paddies, timing should be considered and recorded.

\subsection{Soil Properties and Water Quality in Rice Paddies}

Soil properties of conventional and organic paddies in different seasons are presented in Fig. 4 by average and standard error. As shown in the ANOVA, all soil properties, except $\mathrm{pH}$ and $\mathrm{NH}_{4}-\mathrm{N}$, were significantly different depending on temporal variation. Duncan's multiple range tests were adopted to compare the means of soil properties. A significant difference in $\mathrm{pH}$ between conven- tional and organic paddies was not observed. This result is similar to that of Lopes et al. [19], who observed that $\mathrm{pH}$ in organic and conventional paddies differed significantly only in April within the whole rice cycle. Flooded and reducing conditions increase the soil $\mathrm{pH}$, but $\mathrm{pH}$ decreases after draining [20]. However, such an observation was not observed in this study during the rice-growing period. In both the conventional and organic paddies, water content varied significantly throughout the rice cycle. Water content was higher in May and August than in other seasons because the paddies were submerged. EC in soils was higher after harvesting than in other seasons, and EC in conventional paddies was higher than in organic paddies. Clark et al. [8] also observed that EC levels in the organic system were stable, and they concluded that animal manures did not increase salinity in soil. OM was higher in August than in other seasons. This result may be due to the application of additional fertilizer in August, but basal fertilization did not increase the OM content in soil because of tillage after basal fertilization. Higher OM content was observed in conventional paddy soil than in organic paddy soil. This result was inconsistent with our expectation, but such a discrepancy could be explained by the fact that a lot of animal manure, as an alternative to inorganic chemical fertilizer, was used in the conventional paddies. Inorganic fertilizer application was regulated from the late 1990s in Korea [20]. Organic fertilizer was also used in organic paddies, but the amount was regulated to obtain certification as an organic product.

Nutrients, namely $\mathrm{N}$ and $\mathrm{P}$ concentrations, in the soils of organic and conventional paddies are shown in Fig. 4(e)-(f). Both $\mathrm{N}$ and $\mathrm{P}$ are indispensable elements for enabling profitable plant growth, but excess amounts of these in soils can deteriorate water quality by runoff. In the case of $\mathrm{P}$, the threshold concentration for runoff is near the level sufficient for optimal plant growth, and an optimal profitable level of $\mathrm{P}$ fertility should be maintained for both optimal plant growth and a sound environment [21]. T-N concentration in conventional paddies was higher than that in organic paddies in March and May. As described previously, principal component analysis showed that the soils from August were characterized by high concentrations of WC, OM, and T-N. In the ANOVA, WC and OM were also highest in August, but T-N concentration of conventional paddy soil in May was higher than that in August. This observation could be due to the large dispersion of T-N data of conventional paddy soil in August. Higher $\mathrm{NH}_{4}-\mathrm{N}$ was observed in conventional paddy soil compared with organic paddy soil during March. $\mathrm{NO}_{3}-\mathrm{N}$ concentration was highest in March in both conventional and organic paddies. $\mathrm{NH}_{4}-\mathrm{N}$ and $\mathrm{NO}_{3}-\mathrm{N}$ concentrations were much lower than $\mathrm{T}-\mathrm{N}$, thereby indicating that most of the $\mathrm{N}$ was present in organic form. A significant difference in T-P concentration between conventional paddies and organic paddies was not observed, but this concentration varied over the rice cycle. The highest T-P concentration was observed in May, after basal fertilization, but the highest $\mathrm{P}_{2} \mathrm{O}_{5}$ concentration was observed in October. Time is required for mineralization of organic $\mathrm{P}$, so $\mathrm{P}$ fertilization should be performed earlier than May. In Korea, the recommended concentration of $\mathrm{P}_{2} \mathrm{O}_{5}$ in soil is $80-120$ mg $\mathrm{P}_{2} \mathrm{O}_{5} \mathrm{~kg}^{-1}$ [22], but the $\mathrm{P}_{2} \mathrm{O}_{5}$ levels of paddy soils in Korea have been reported to be high as a result of high applications of inorganic $\mathrm{P}$ [23]. $\mathrm{P}_{2} \mathrm{O}_{5}$ concentrations 

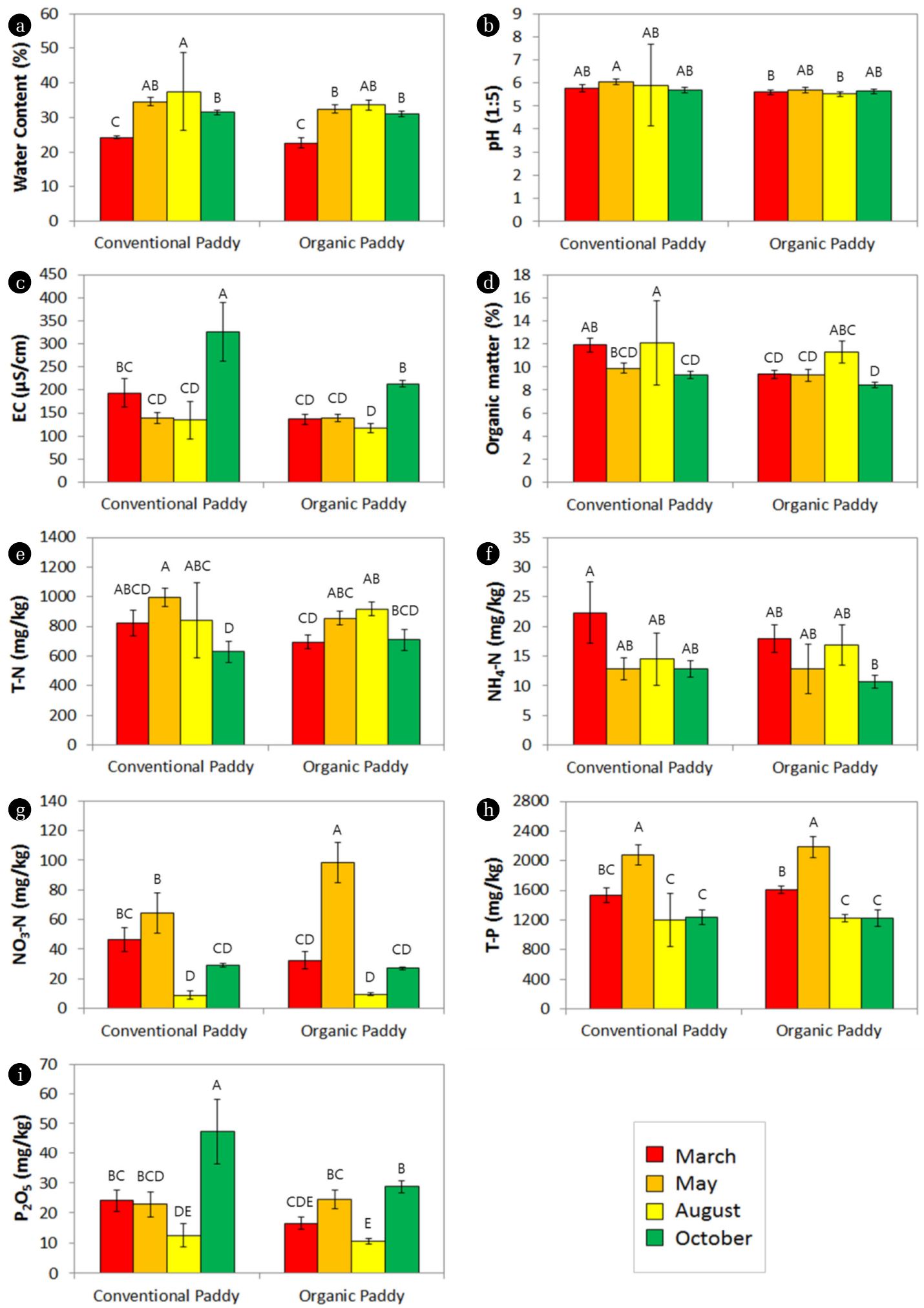

Fig. 4. Comparison of chemical properties according to farming method and seasonal variation. The different letters that appear above the bars are the significant differences according to Duncan's multiple range test $\left(p<0.05\right.$ ). (a) WC, (b) $\mathrm{pH}$, (c) $\mathrm{EC},(\mathrm{d}) \mathrm{OM},(\mathrm{e}) \mathrm{T}-\mathrm{N}$, (f) $\mathrm{NH} \mathrm{H}_{4}-\mathrm{N}$, (g) $\mathrm{NO}_{3}-\mathrm{N}$, (h) $\mathrm{T}-\mathrm{P}$, (i) $\mathrm{P}_{2} \mathrm{O}_{5}$. 

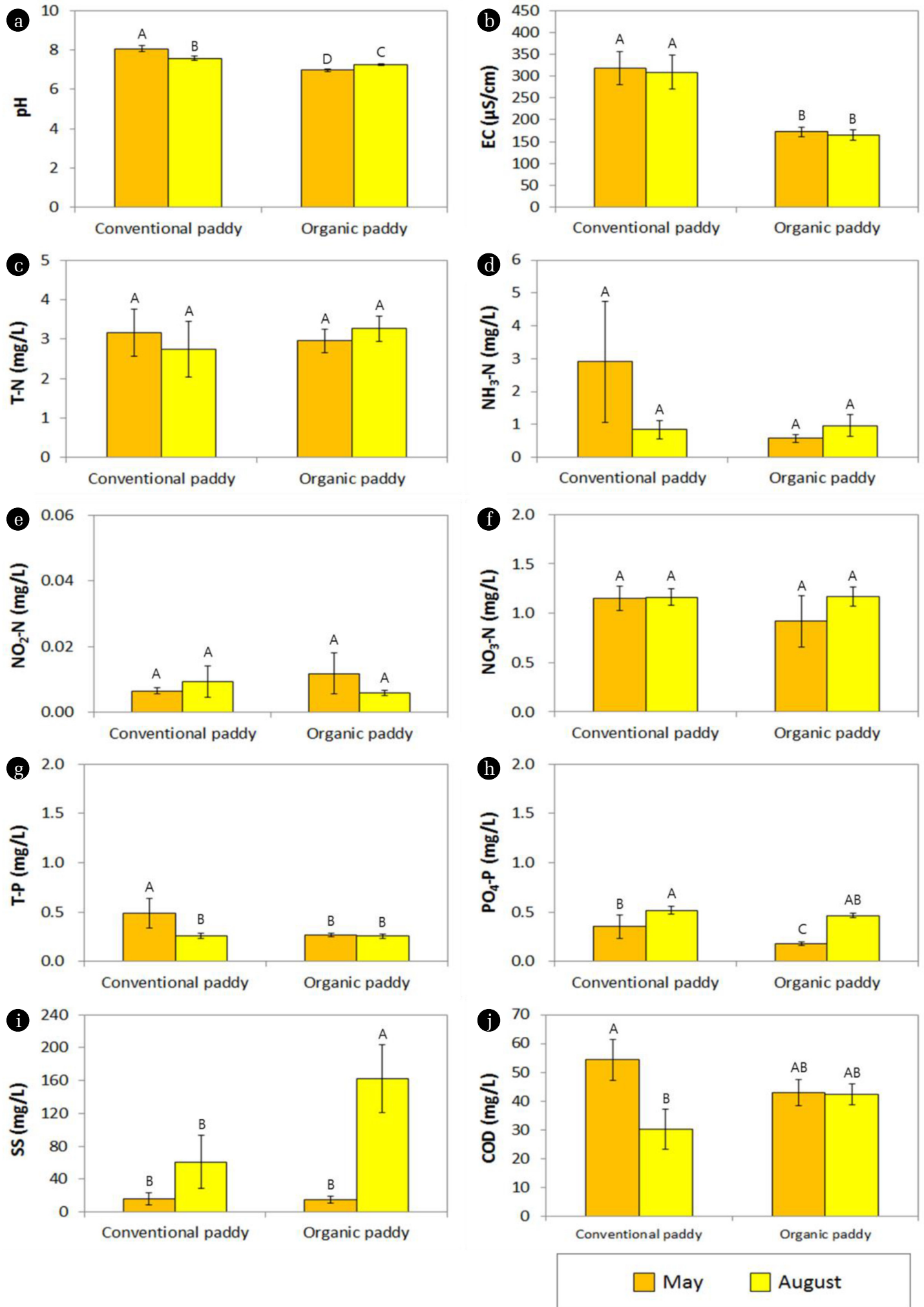

Fig. 5. Comparison of water quality according to a farming method and seasonal variation. The different letters that appear above the bars are the significant differences according to Duncan's multiple range test ( $p<0.05$ ). (a) $\mathrm{pH}$, (b) $\mathrm{EC}$, (c) $\mathrm{T}-\mathrm{N},(\mathrm{d}) \mathrm{NH}_{3}-\mathrm{N},(\mathrm{e}) \mathrm{NO}_{2}-\mathrm{N}$, (f) $\mathrm{NO}_{3}-\mathrm{N}$, (g) $\mathrm{T}-\mathrm{P}$, (h) $\mathrm{PO}_{4}-\mathrm{P}$, (i) $\mathrm{SS}$, (j) COD. 
in soils in this study ranged from $2.52-138.37 \mathrm{mg} \mathrm{kg}^{-1}$, and $98.6 \%$ of $\mathrm{P}_{2} \mathrm{O}_{5}$ data were less than $80 \mathrm{mg} \mathrm{kg}^{-1}$, thereby indicating that $\mathrm{P}_{2} \mathrm{O}_{5}$ concentrations in most of the investigated fields were lower than the optimum range.

Given the fact that similar soil properties were observed in organic and conventional paddies, it could be argued that the type of agricultural management practice did not have a major influence on the water and soil properties in the rice paddies. Because rice culturing is unique due to its inclusion of a long period of flooded conditions, farming management might trigger responses in soil properties that are different from those observed for other crops [19, 24]. As organic and conventional paddies have a similar rice production cycle, including fertilization, tillage, and irrigation, soil properties were less influenced by farming methods than by seasonal variation. Both organic and conventional farming used animal manure as a basal fertilizer, but the animal manure used for organic farming was supplied from a stock farm certified as not using antibiotics. Such a similar fertilization system of organic and conventional farming lead to an insignificant difference in soil properties between organic and conventional paddies.

Water quality in the organic and conventional paddies in different seasons is presented in Fig. 5. Ponded water in paddies was collected along with soil samples in May and August because the paddy fields in this study were in the flooding phase during the period of May to August. Duncan's multiple range tests showed that T-N, $\mathrm{NH}_{3}-\mathrm{N}, \mathrm{NO}_{2}-\mathrm{N}$, and $\mathrm{NO}_{3}-\mathrm{N}$ concentrations were not statistically different by either farming method or season. $\mathrm{pH}, \mathrm{EC}$, and $\mathrm{PO}_{4}-\mathrm{P}$ of ponded water in the conventional paddies were higher than those of organic paddies, but a lower concentration of SS was observed in the conventional paddies than in the organic paddies. In conventional paddy water, higher $\mathrm{pH}$, T-P, and COD levels were observed in May than in August, but lower $\mathrm{PO}_{4}-\mathrm{P}$ was observed in May than in August. In the organic paddies, $\mathrm{pH}, \mathrm{PO}_{4}-\mathrm{P}$, and SS concentrations were lower in May than in August. Ponded water quality, which was dependent on seasonal variation, followed the same trend as the results of soil properties, but the farming method also influenced water quality. The difference in water quality depending on the farming method was ascribed to irrigation water. The organic paddies were irrigated with groundwater, but in the conventional paddies, reservoir water was supplied using an irrigation canal.

\section{Conclusions}

The influences of farming methods and time within the rice growing cycle on soil and water properties were investigated. Soil and water were sampled from 24 organic paddy plots and 11 conventional paddy plots, followed by chemical analyses of soil and water and statistical analyses to compare the influences of the two factors. ANOVA results showed that there were differences in WC, EC, $\mathrm{OM}$, and T-P between organic and conventional paddy soil, but all soil properties, except for $\mathrm{pH}$ and $\mathrm{NH}_{4}-\mathrm{N}$, were significantly different with regard to seasonal variation. Cluster analysis and principal component analysis indicated that soil properties were more dependent on seasonal variation than on the farming method.
Such a relatively small difference between organic and conventional paddy soil was attributed to the fact that animal fertilizer was used in both organic and conventional paddies as basal fertilizer. However, water quality data were dependent on the farming method as well as seasonal variation. Higher EC of both water and soil was observed in conventional paddies compared with that in organic paddies. In this study, the influence of seasonal variation on soil properties was also significant, along with the farming method. Best management practices should be performed considering seasonal variation in soil and water in paddies.

\section{Acknowledgments}

This study was conducted with the support of the 'Cooperative Research Program for Agricultural Science \& Technology Development' (PJ01086103) of the Rural Development Administration of the Republic of Korea.

\section{References}

1. Lairon D. Nutritional quality and safety of organic food. A review. Agron. Sustain. Dev. 2010;30:33-41.

2. Keyes S, Tyedmers P, Beazley K. Evaluating the environmental impacts of conventional and organic apple production in Nova Scotia, Canada, through life cycle assessment. J. Clean. Prod. 2015;104:40-51.

3. Suja G, Byju G, Jyothi AN, Veena SS, Sreekumar J. Yield, quality and soil health under organic vs conventional farming in taro. Sci. Hortic. 2017;218:334-343.

4. Seufert V, Ramankutty N, Foley JA. Comparing the yields of organic and conventional agriculture. Nature 2012;485:229-232.

5. Anglade J, Billen G, Garnier J, Makridis T, Puech T, Tittel C. Nitrogen soil surface balance of organic vs conventional cash crop farming in the Seine watershed. Agr. Syst. 2015;139:82-92.

6. Marchand S, Huanxiu GUO. The environmental efficiency of non-certified organic farming in China: A case study of paddy rice production. China Econ. Rev. 2014;31:201-216.

7. Marinari S, Mancinelli R, Campiglia E, Grego S. Chemical and biological indicators of soil quality in organic and conventional farming systems in Central Italy. Ecol. Indic. 2006;6:701-711.

8. Clark MS, Horwath WR, Shennan C, Scow KM. Changes in soil chemical properties resulting from organic and low-input farming practices. Agron. J. 1998;90:662-671.

9. Stockdale EA, Lampkin NH, Hovi M, et al. Agronomic and environmental implications of organic farming systems. AdV. Agron. 2001;70:261-327.

10. Schjønning P, Elmhot S, Munkholm LJ, Debosz K. Soil quality aspects of humid sandy loams as influenced by organic and conventional long-term management. Agr. Ecosyst. Environ. 2002;88:195-214.

11. Gosling P, Shepherd M. Long-term changes in soil fertility in organic arable farming systems in England, with particular reference to phosphorus and potassium. Agr. Ecosyst. Environ. 2005;105:425-432.

12. da Silva AM, Manfre LA, Urban RC, Silva VHO, Manzatto 
MP, Norton LD. Organic farm does not improve neither soil, or water quality in rural watersheds from southeastern Brazil. Ecol. Indic. 2015;48:132-146.

13. Mazzoncini M, Canali S, Giovanetti M, et al. Comparison of organic and conventional stockless arable systems: A multidisciplinary approach to soil quality evaluation. J. Appl. Ecol. 2010;44:124-132.

14. Arnhold S, Lindner S, Lee B, et al. Conventional and organic farming: Soil erosion and conservation potential for row crop cultivation. Geoderma 2014;219:89-105.

15. Eltun R, Korsæth A, Nordheim O. A comparison of environmental, soil fertility, yield, and economical effects in six cropping systems based on an 8-year experiment in Norway. Agr. Ecosyst. Environ. 2002;90:155-168.

16. Sharaf MA, Illman DL, Kowalski BR. Chemometrics. New York: Wiley; 1986. p. 219-227.

17. Ward Jr JH. Hierarchical grouping to optimize an objective function. J. Am. Stat. Assoc. 1963;58:236-244.

18. Martens H, Naes T. Multivariate calibration. New York: Wiley; 1989. p. 97-108.
19. Lopes AR, Faria C, Prieto-Fernández Á, Trasar-Cepeda C, Manaia CM, Nunes OC. Comparative study of the microbial diversity of bulk paddy soil of two rice fields subjected to organic and conventional farming. Soil Biol. Biochem. 2011; 43:115-125.

20. Minasny B, Hong SY, Hartemink AE, Kim YH, Kang SS. Soil $\mathrm{pH}$ increase under paddy in South Korea between 2000 and 2012. Agr. Ecosyst. Environ. 2016;221:205-213.

21. Brady NC, Weil RR. Elements of the nature and properties of soils. 3rd ed. London: Pearson; 2014.

22. RDA. Fertilization standard of crop plant. Suwon: Rural Development Agency of Korea. 1999.

23. Jo IS, Koh MH. Chemical changes in agricultural soils of Korea: Data review and suggested countermeasures. Environ. Geochem. Health 2004;26:105-117.

24. Sheng ZL, Min L, Yong HC, Abid S. Effects of nutrient and pest management on soil microorganism in hybrid rice doubleannual cropping system. Commun. Soil Sci. Plant. Anal. 2005;36:1525-1536. 